\title{
Contribution of diet type and pasture conditions to the influence of high altitude grazing on intake, performance and composition and renneting properties of the milk of cows
}

\author{
Florian LeIBER, Michael KREUZER*, Hans LEUENBERGER, \\ Hans-Rudolf WETTSTEIN
}

\author{
Institute of Animal Science, Swiss Federal Institute of Technology (ETH), ETH Centre/LFW, \\ CH-8092 Zürich, Switzerland
}

(Received 6 January 2005; accepted 8 September 2005)

\begin{abstract}
Individual factors contributing to the influence of high altitude grazing on milk synthesis and quality were investigated in three groups of six cows each. After an initial period, where all cows received a silage-concentrate control diet, two groups were offered only grass further on, the third received the control diet and stayed in the barn in the lowlands. Grass-fed cows were either kept on pasture or in barn and were subjected to four experimental periods, two of them at $400 \mathrm{~m}$ a.s.l. and two at $2000 \mathrm{~m}$ a.s.l. Young and mature swards were grazed consecutively at each altitude. In the lowlands, feeding grass instead of the control diet did not clearly affect intake and performance but increased dietary $\mathrm{N}$ conversion ratio into milk protein and casein number. Relative to the control, rennet coagulation properties of the milk were improved on pasture but not with grass fed in barn. At the alpine site, nutrient and energy intake was depressed during the entire alpine period, presumably because of a combination of decrease in intake related to hypoxia and lower digestibility of the grass. Indications for elevated maintenance energy requirements caused by high altitude and, less so, by grazing activity were found. Compared to lowland, milk yield, milk protein content and $\mathrm{N}$ utilisation were lower at high altitude. Curd firmness was impaired by high altitude grazing at unchanged rennet coagulation time. The effects of grass maturity remained low at both altitudes despite contrasting digestibilities measured in young and mature swards. The plasminogen-derived activity in the milk declined with increasing sward maturity and with altitude, while plasmin activity was increased by sward maturity. Overall, diet type (control vs. alpine grass) and hypoxia-related factors seem to be more important for the expression of the known effects of alpine summer grazing than grazing activity as such and maturity of the sward.
\end{abstract}

dairy cows / hypoxia / milk protein / plasmin / cheese

Résumé - Contribution du type de ration et de la maturité des fourrages à l'influence d'un séjour au pâturage à haute altitude sur les quantités d'aliments ingérées, la quantité de lait produite et sa composition ainsi que ses propriétés de coagulation chez les vaches laitières. Les

* Corresponding author: michael.kreuzer@inw.agrl.ethz.ch 
facteurs individuels contribuant à l'influence du pâturage à haute altitude sur la quantité de lait produite et sa qualité ont été analysés avec trois lots de six vaches chacun. Après une période initiale, où toutes les vaches ont été nourries avec une même ration témoin composée d'ensilage et de concentré, deux lots ont reçu uniquement de l'herbe et le troisième une ration témoin, à l'étable, en plaine. Les vaches alimentées avec l'herbe ont été gardées soit au pâturage, soit à l'étable, et étaient exposées à quatre périodes expérimentales, deux d'entre elles à $400 \mathrm{~m}$ d'altitude et deux à $2000 \mathrm{~m}$. Des pâturages jeunes ou matures ont été offerts consécutivement à chaque altitude. En plaine, le remplacement de la ration témoin par de l'herbe n'a affecté ni les quantités ingérées ni les performances mais a augmenté le taux de conversion de l'azote alimentaire en protéines du lait et le rapport caséines/protéines. Par rapport à la ration témoin, les propriétés de coagulation du lait ont été améliorées au pâturage, mais pas avec l'herbe distribuée à l'étable. En montagne, l'ingestion de nutriments et d'énergie a été plus faible durant toute la période expérimentale, vraisemblablement en raison de la combinaison de deux facteurs : la baisse de consommation liée à une hypoxie et la faible digestibilité de l'herbe. Des indications montrant les besoins énergétiques d'entretien élevés causés par la haute altitude et l'activité de pâturage ont été trouvées. Comparées à la plaine, les performances laitières, les teneurs en protéines du lait et l'utilisation de $\mathrm{N}$ ont été plus basses à haute altitude. La fermeté du caillé a été plus faible à haute altitude pour des temps de coagulation inchangés. Les effets de la maturité de l'herbe sont restés faibles aux deux altitudes malgré des digestibilités différentes entre les pâturages jeunes et matures. Dans le lait, l'activité dérivée du plasminogène a diminué avec l'augmentation de la maturité du fourrage et avec l'altitude, alors que l'activité de la plasmine augmentait avec l'âge du fourrage. Dans l'ensemble, le type de ration (témoin vs. herbage alpin) et les facteurs liés à l'hypoxie semblent être plus importants pour l'expression des effets connus du pâturage en montagne que l'activité de pâturage en soi ou l'âge du fourrage.

vaches laitières / hypoxie / protéines du lait / plasmine / fromage

\section{INTRODUCTION}

Moderately intensive grazing is an appropriate means to maintain a high plant biodiversity in grassland areas [40]. Mountainous sites are traditionally used for summer grazing of ruminants across the alps, and dairy production at high altitude (up to $2500 \mathrm{~m}$ a.s.l.) represents one important and comparably efficient [22] agricultural niche production system in Europe. Hard cheese is an important product manufactured in these systems; thus milk protein and fat contents and, particularly, rennet coagulation properties are the economic basis of these farmers' success. The milk protein content is often considerably depressed at high altitude $[14,33,45]$, although this is not a general rule [43]. While other milk quality changes are clearly advantageous [29, 32], protein quality and cheese-making properties have been reported to be adversely influenced by high alpine sojourn of cows [5, 33]. It is still unclear if and how milk activity of plasmin, as one important endogenous protease potentially influencing curd firmness and cheese-ripening, and its precursor, plasminogen, are influenced by high altitude grazing [12, 33].

An alpine period comprises a number of factors, which may influence nutritional status and metabolism of cows and thus yield and composition of their milk. The typically limited intensity of pasture management and mineral fertilisation results in a comparably low nutritional value of the pastures [24]. Additionally, the short vegetative period facilitates a rapid maturation of the sward, with the consequence of high fibre contents and low digestibility [10]. Furthermore, altitude-related hypoxia [27] and harsh climatic conditions, such as cold and rainy weather or occasional snowfall, is presumed to increase the cow's maintenance requirements for energy on alpine pastures [14]. A further important phenomenon related to high altitude is a considerably reduced feed intake, which was repeatedly observed during adaptation $[6,26,31]$ and sometimes even longer [14], although the latter was reported only for cows kept indoors. 
In two multi-factorial experiments, we separately analysed the influence of individual factors associated with a high altitude period in order to achieve a deeper insight in the effects of alpine summer grazing and to facilitate the identification of efficient management options by the determination of the relative importance of these factors. A first experiment compared standardised forages grown at two different altitudes and fed alternatively at both altitudes, and included the comparison with a typical silage-concentrate lowland diet [31, 33]. This allowed the separation of direct altitude effects and diet effects, but was only possible with hay and under indoor conditions. The results indicated that diet affects performance, milk composition and cheesemaking properties similarly or even more than altitude as such [31, 33]. However, altitude effects could be more pronounced on pasture, and interactions with maturity of the sward may mask either altitude or diet type effects. The present experiment was therefore designed to evaluate the interaction of the direct effects of altitude with sward maturity and grazing activity. Like in the previous experiment, a group fed a typical mixed lowland diet was included to be able to relate the magnitude of the grassrelated effects to the overall diet effects. Focus was put on feed intake, digestibility, performance and milk composition, with special emphasis on cheese-making properties. The effects on milk fatty acid profile are reported elsewhere [32].

\section{MATERIALS AND METHODS}

\subsection{Experimental design, animals and feeds}

The experiment started in March 2002 at the ETH research station Chamau in central Switzerland at $400 \mathrm{~m}$ a.s.l. A total of 18 Brown Swiss dairy cows, all in their second lactation, and at 94 (65 to 127) days in milk were used. Milk yield, on average of the first lactation, had been 20.1 (s.d. 2.6) $\mathrm{kg} \cdot \mathrm{d}^{-1}$.
The cows were allocated to three experimental groups which were balanced for a minimal between-group variance for calving date, energy-corrected milk yield, milk protein, milk fat and frequency of the $\kappa$-casein allele B. Initially, cows of the three groups yielded on average 21.7, 22.2 and $22.3 \mathrm{~kg}$ milk $\cdot \mathrm{d}^{-1}$. The corresponding contents per $\mathrm{kg}$ of milk were $43.6,42.0$ and $41.4 \mathrm{~g}$ fat, $30.3,31.1$ and $31.8 \mathrm{~g}$ protein, and 50.6, 50.4 and $49.1 \mathrm{~g}$ lactose, respectively. During a baseline sub-period (S0), all cows were fed the mixed control diet in a barn. In the actual experimental phase, the cows were either fed grass and kept on pasture $(\mathrm{P})$ or in barn (B) or were fed a control diet in the barn (C) (Tab. I). From early April on, group P was fulltime grazed. Simultaneously, group B was offered freshly cut grass ad libitum in the barn, whereas group $\mathrm{C}$ was fed the control diet further on. The lowland period lasted for two consecutive sub-periods (S1 and $\mathrm{S} 2$, representing young and mature sward, respectively) comprising two weeks of adaptation and one intensive sampling week, each. Grass feeding in groups $\mathrm{P}$ and $\mathrm{B}$ was started at the earliest possible vegetative stage of the first growth in S1; S2 followed three weeks later in paddocks with the same botanical composition. After S2 all cows were kept in the barn again, but groups $\mathrm{P}$ and $\mathrm{B}$ still received only grass ad libitum. In mid-June, when the earliest possible vegetative stage for grazing at high altitude was reached, groups $\mathrm{P}$ and $\mathrm{B}$ were transferred to the alpine ETH research station Alp Weissenstein located at $2000 \mathrm{~m}$ a.s.l. in the Eastern Swiss Alps. At that time, half of the former group $P$ and B cows were switched to the respective other treatment as a means to account for any residual effects of the previous treatment. After one week of adaptation to the alpine conditions, the two following sub-periods (S3 and S4) were carried out similarly to those in the lowlands. Again, each sub-period comprised two weeks of adaptation and one intensive sampling week. Group C cows remained in the lowlands. After relocation of all cows to the lowlands, a final baseline 
Table I. Experimental design.

\begin{tabular}{|c|c|c|c|c|c|c|c|c|c|c|}
\hline \multirow[t]{2}{*}{ Period } & \multirow{2}{*}{$\begin{array}{l}\text { Sub- } \\
\text { period }\end{array}$} & \multicolumn{3}{|c|}{ Pasture group $(\mathrm{P})$} & \multicolumn{3}{|c|}{ Barn group (B) } & \multicolumn{3}{|c|}{ Control group (C) } \\
\hline & & Diet & $\begin{array}{l}\text { Feeding } \\
\text { regime }\end{array}$ & $\begin{array}{l}\text { Altitude } \\
\text { (m a.s.l.) }\end{array}$ & Diet & $\begin{array}{c}\text { Feeding } \\
\text { regime }\end{array}$ & $\begin{array}{l}\text { Altitude } \\
\text { (m a.s.l.) }\end{array}$ & Diet & $\begin{array}{l}\text { Feeding } \\
\text { regime }\end{array}$ & $\begin{array}{l}\text { Altitude } \\
\text { (m a.s.1.) }\end{array}$ \\
\hline Lowland & $\mathrm{SO}^{2}$ & Mixed $^{3}$ & Barn & 400 & Mixed & Barn & 400 & Mixed & Barn & 400 \\
\hline Lowland & S1 & $\begin{array}{l}\text { Young } \\
\text { grass }\end{array}$ & Pasture & 400 & $\begin{array}{l}\text { Young } \\
\text { grass }\end{array}$ & Barn & 400 & Mixed & Barn & 400 \\
\hline Lowland & $\mathrm{S} 2$ & $\begin{array}{c}\text { Mature } \\
\text { grass }\end{array}$ & Pasture & 400 & $\begin{array}{c}\text { Mature } \\
\text { grass }\end{array}$ & Barn & 400 & Mixed & Barn & 400 \\
\hline Alpine ${ }^{1}$ & S3 & $\begin{array}{l}\text { Young } \\
\text { grass }\end{array}$ & Pasture & 2000 & $\begin{array}{l}\text { Young } \\
\text { grass }\end{array}$ & Barn & 2000 & Mixed & Barn & 400 \\
\hline Alpine ${ }^{1}$ & S4 & $\begin{array}{c}\text { Mature } \\
\text { grass }\end{array}$ & Pasture & 2000 & $\begin{array}{c}\text { Mature } \\
\text { grass }\end{array}$ & Barn & 2000 & Mixed & Barn & 400 \\
\hline Lowland & $\mathrm{S} 5^{2}$ & Mixed & Barn & 400 & Mixed & Barn & 400 & Mixed & Barn & 400 \\
\hline
\end{tabular}

1 Only groups $\mathrm{P}$ and $\mathrm{B}$.

2 Baseline periods.

3 Mixed diet as described in Table II.

evaluation (S5) was carried out with all cows fed the control diet again.

Group P grazed paddocks of sizes of 1.2, 1.2, 1.8 and 1.6 ha per week in S1, S2, S3 and $\mathrm{S} 4$, respectively, with the allocated area depending on estimated sward biomass. Pastures were sub-divided, and new areas were allocated twice per day. The size of the new areas was determined by the intensity that the previous one had been grazed in order to guarantee ad libitum availability of grass and, simultaneously, to avoid excessive trampling losses. On average, pre-grazing sward heights were $12 \pm 2,16 \pm 4,10 \pm$ 4 and $14 \pm 4.5 \mathrm{~cm}$ in S1, S2, S3 and S4, respectively, and the corresponding postgrazing values were $4 \pm 1,7 \pm 3,5 \pm 3$ and $6 \pm 4 \mathrm{~cm}$. Grass for group B was always harvested in areas of similar botanical composition adjacent to the paddocks grazed by group $\mathrm{P}$ cows. The lowland areas were intensively managed and fertilised leys, dominated by three poaceae species (Lolium multiflorum, Lolium perenne and Poa trivialis). The biodiversity of the native, less intensively managed and non-fertilised (except from excreta returns) alpine pasture was much higher (71 species), and grass, legume and herb species were well balanced. The control diet was composed of forage (hay, ryegrass silage and maize silage in proportions of 10:60:30 on a dry matter (DM) basis) offered at ad libitum access and of concentrates allocated by considering forage intake and requirements for milk yield. The average concentrate proportion of the control diet was $326 \mathrm{~g} \cdot \mathrm{kg}^{-1}$ DM. Additionally, all cows were offered $\mathrm{NaCl}$ and a non-vitaminised mineral mix (Ca:P = 2:1, Nährkosan, Büron, Switzerland) ad libitum during the whole experiment.

The cows were milked twice daily with automatic milking systems either in barn (lowland, alpine barn) or with a mobile milking parlour on the alpine pasture. The walking distance from the pasture to the respective milking parlour never exceeded $300 \mathrm{~m}$. The experiment was carried out under the approval of the respective Swiss authority for animal welfare.

\subsection{Experimental procedures}

For cows kept in barn, feed intake was determined by hand-weighing. For pastured cows, during the four intensive sampling 
weeks feed intake and digestibility were determined by applying the double alkane technique [20]. All grass-fed cows received synthetic alkane markers $\left(\mathrm{C}_{32}\right.$ and $\left.\mathrm{C}_{36}\right)$ via controlled-release alkane capsules (CRC, Captec, Auckland, New Zealand) being introduced into the rumen of the cows $8 \mathrm{~d}$ prior to the sampling week of each subperiod. An uneven chain alkane $\left(\mathrm{C}_{31}\right)$ in feed was used as internal marker. On pasture, collection of grass samples, representative for intake, were collected by alternately mimicking the selection behaviour of individual cows for at least $3 \mathrm{~h}$ distributed over the whole daytime. The cows had been adapted to being closely accompanied in the respective adaptation periods. Two independent feed samples were taken across the day in every group. Rectal grab samples of faeces were obtained from each grass-fed cow between 04.00 and $05.30 \mathrm{~h}$ every day during the sampling weeks, since the morning has been identified as the optimal time to get representative samples [4, 22]. Feed and faeces samples were immediately frozen at $-20^{\circ} \mathrm{C}$. The actual alkane release rates of the capsules were calculated for each sampling week from the group B cows with known herbage intake which had also received CRC. The Pearson correlation between handweighed amounts of feed intake and alkanebased estimates in group B was 0.91. At the end of each sampling week, feed and faeces samples were thawed, composited per cow across days per period, dried at $60{ }^{\circ} \mathrm{C}$ (feed for $48 \mathrm{~h}$, faeces for $72 \mathrm{~h}$ ) and ground with a particle size of $0.75 \mathrm{~mm}$.

The cows were weighed twice within each sampling week. During the sampling weeks, milk yield was recorded and proportionate milk samples of each cow and each milking were obtained. One portion was stabilised with 2-bromo-2-nitropropane-1,3diol (Bronopol; D\&F Inc., Dublin, CA, USA) and a second aliquot was frozen at $-20{ }^{\circ} \mathrm{C}$ immediately after sampling.

Climatic data were followed at both experimental sites with automatic data recording stations (Markasub, Basle, Switzerland).

\subsection{Laboratory analyses}

The contents of DM, organic matter $(\mathrm{OM})$, nitrogen (crude protein, $\mathrm{CP} ; 6.25 \times$ $\mathrm{N}$ ), neutral (NDF) and acid detergent fibre (ADF) of feeds and faeces were analysed using standard procedures as described in Leiber et al. [31]. Alkane contents of feeds and faeces were determined by gas chromatography after saponification and purification as outlined in Berry et al. [4]. The contents of net energy for lactation (NEL) and absorbable protein at the duodenum (PDI) in feeds as well as requirements for NEL and PDI of each individual cow were calculated from the analysed proximate contents applying the official Swiss regressions [38]. Fat, protein, lactose, urea and somatic cell count in milk were measured daily in the Bronopol-stabilised milk using a Milkoscan 4000 (Foss Electric, Hillerød, Denmark). Casein and true protein content of milk was measured using a modification [33] of the C4 column RP-HPLC method of Bordin et al. [8]. The casein number $(\mathrm{CN})$ was then calculated as casein-to-total true protein ratio. Plasmin and plasminogenderived activities were measured by a spectrofluorometer [33] following a modification of the method of Richardson and Pearce [39]. The activities are given as amidomethylcoumarin (AMC [33]) units being equivalent to the release of $1 \mathrm{ng} \mathrm{AMC} \cdot \mathrm{L}^{-1} \cdot \mathrm{min}^{-1}$. Rennet coagulation properties were analysed on a Lattodinamografo (Foss, Padua, Italy; [33]). Rennet coagulation time (RCT) is defined as the time (min) from rennet addition to the onset of coagulation; $\mathrm{K}_{20}$ (as a measure for coagulation dynamics) represents the time from the onset of coagulation until a defined curd firmness $(20 \mathrm{~mm}$ measurement amplitude) is reached, and $A_{2 R}$ (as a measure for curd firmness) is equivalent to the amplitude describing curd firmness after two times the RCT.

\subsection{Statistical analysis}

Data were evaluated using the SAS V 8.2 Software (SAS Institute, Cary, NC, USA). 
In order to separate the influence of the different factors investigated, two different mixed models were applied. In model 1 , baseline periods and the control group were excluded:

Model 1: $\mathrm{Y}_{\mathrm{ijklm}}=\mathrm{A}_{\mathrm{i}}+\mathrm{R}_{\mathrm{j}}+\mathrm{M}_{\mathrm{k}}+\mathrm{C}_{\mathrm{l}}+\mathrm{I}+$ $\mathrm{A} \times \mathrm{R}_{\mathrm{ij}}+\mathrm{A} \times \mathrm{M}_{\mathrm{ik}}+\mathrm{R} \times \mathrm{M}_{\mathrm{jk}}+\mathrm{COV}(\mathrm{Z})+$ $\varepsilon_{\mathrm{ijklmn}}$

where $\mathrm{A}$ is altitude (lowland vs. high altitude), $\mathrm{R}$ is feeding regime (pasture vs. barn), $\mathrm{M}$ is maturity stage of the grass (young vs. mature), $\mathrm{C}$ is block of cows of similar calving date (three blocks), I is individual animal as a random effect and - for milk traits only $-\mathrm{Z}$ is a covariable representing the baseline values measured in sub-period S0. Model 2 was applied to evaluate the significance of the differences (i) among groups within sub-periods and (ii) among sub-periods within groups. All groups and sub-periods were included in model 2:

Model 2: $\mathrm{Y}_{\mathrm{ijklm}}=\mathrm{G}_{\mathrm{i}}+\mathrm{S}_{\mathrm{j}}+\mathrm{C}_{\mathrm{k}}+\mathrm{A}_{\mathrm{l}}+$ $\mathrm{G} \times \mathrm{S}_{\mathrm{ij}}+\varepsilon_{\mathrm{ijkl}}$

where $\mathrm{G}$ is group, $\mathrm{S}$ is sub-period, and $\mathrm{C}$ and $A$ are as in model 1. Based on this model, differences among groups and among subperiods were tested by the Tukey procedure.

\section{RESULTS}

\subsection{Climate}

The climatic conditions on pasture were similar among periods within sites and even differences between sites were not very pronounced. Average diurnal temperatures during the sampling weeks were 6.5, 9.7, 8.2 and $9.5^{\circ} \mathrm{C}$ for $\mathrm{S} 1, \mathrm{~S} 2, \mathrm{~S} 3$ and $\mathrm{S} 4$, respectively. The corresponding relative humidity was $82,84,74$ and $76 \%$ and precipitation was $4.1,10.1,7.1$ and $2.0 \mathrm{~L} \cdot \mathrm{m}^{2} \cdot$ day $^{-1}$. There was no systematic difference in precipitation between sites, while wind speed was basically higher at high altitude.

\subsection{Feed quality and composition}

The higher amounts of precipitation occurring in S2 and S3 were associated with clearly lower DM contents of the grass harvested for the barn-fed animals (Tab. II). The contents of OM, NDF and ADF were higher in alpine than in lowland grass, and fibre contents were higher in mature than in young grass. Crude protein and PDI were declining with increasing maturity, but were not affected by altitude. The NEL content of the grass was negatively influenced by maturity and alpine location. Hay and grass silage, as used in the control diet, were inferior in NEL content as compared to the lowland grass, while the maize silage had a similar NEL content. The lower NEL contents of the forages in the control diet were compensated for by the inclusion of the concentrates. The PDI contents were similar in all feeds except maize silage (lower) and protein concentrate (higher).

\subsection{Intake and digestibility of the feed}

The OM intake was slightly reduced in the grass-fed groups in S1, but increased in all groups in S2 (Tab. III). The NDF intake was significantly increased in both grassfed groups when offered mature herbage in S2. NEL intake was maintained while the PDI intake was reduced during the lowland period in all cows (Fig. 1). In the lowland period, none of the groups ran into a deficit of either NEL or PDI even when calculated on the basis of the initial milk yield (Fig. 1). During the entire alpine period, OM intake was lower than in the lowland period (Tab. III). Intake of NDF was lower in the alpine period than in S2. In the barn group, NDF intake significantly increased in S4 as a function of slightly increased OM intakes and NDF contents. Because of the lower energy density of the alpine feed and the reduced feed intake, NEL intake with alpine grass was only 0.74 of that found with lowland grass on average over both groups and sub-periods. This was no longer sufficient to cover requirements for maintenance and 


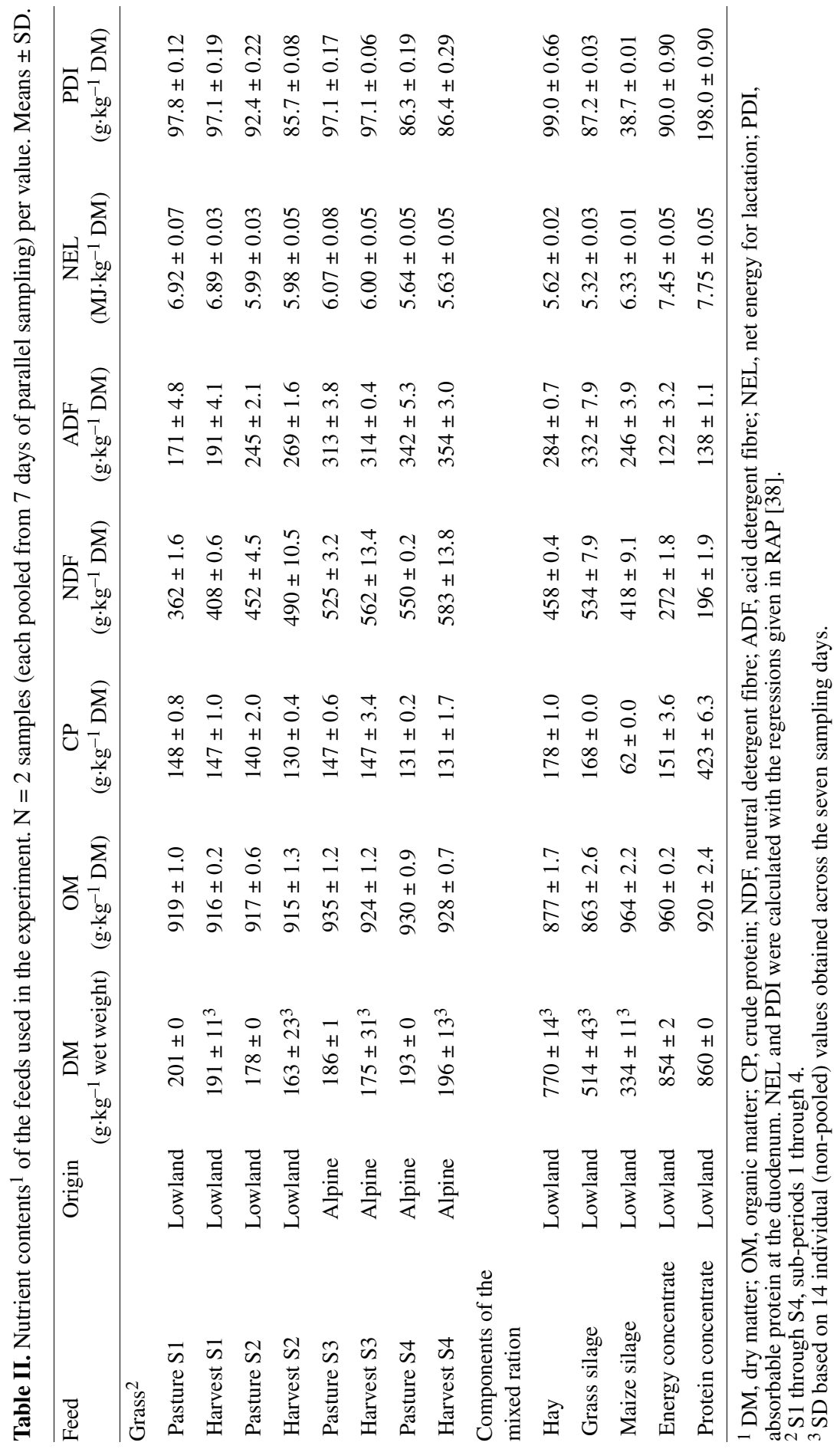


F. Leiber et al.

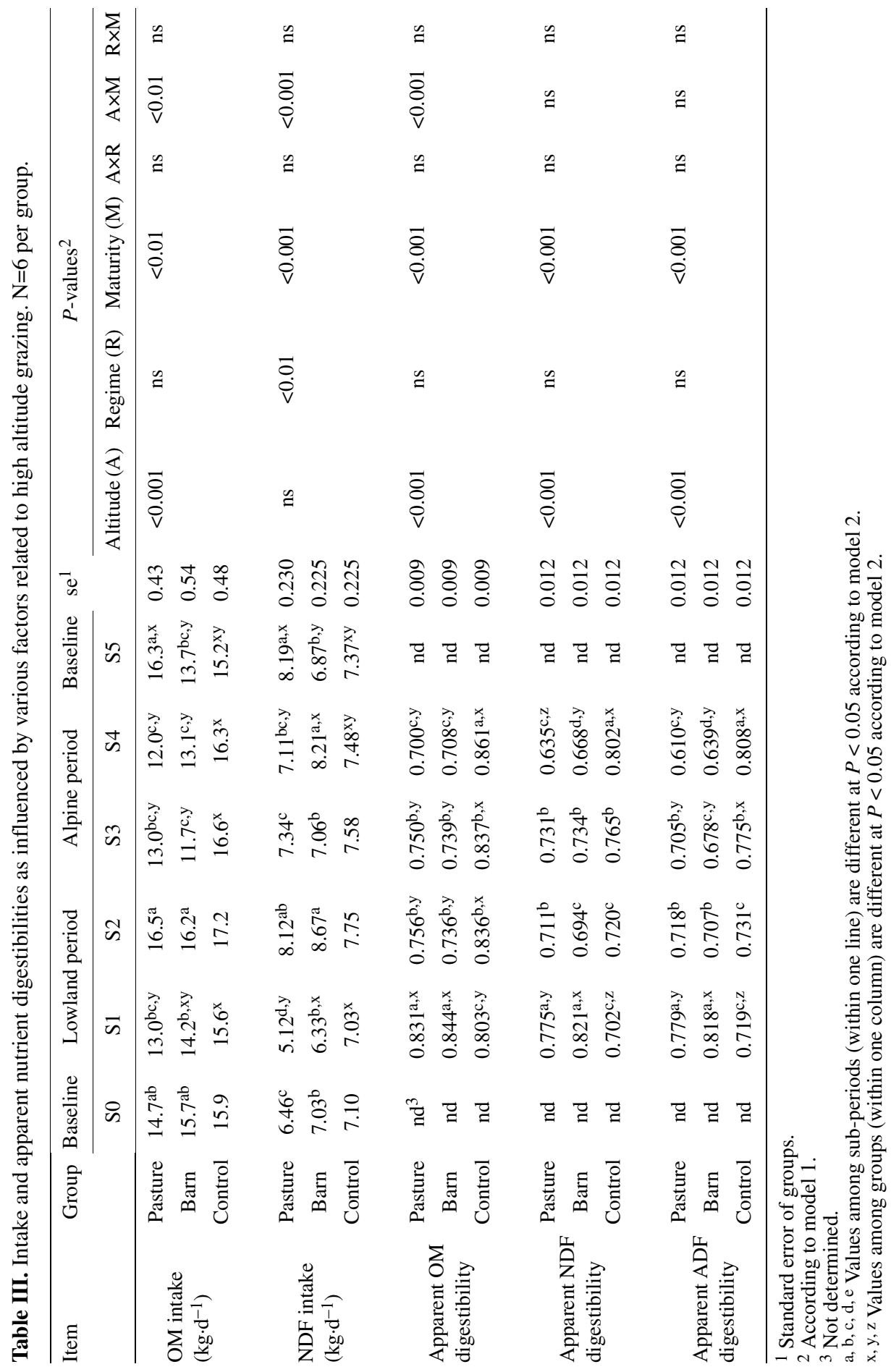



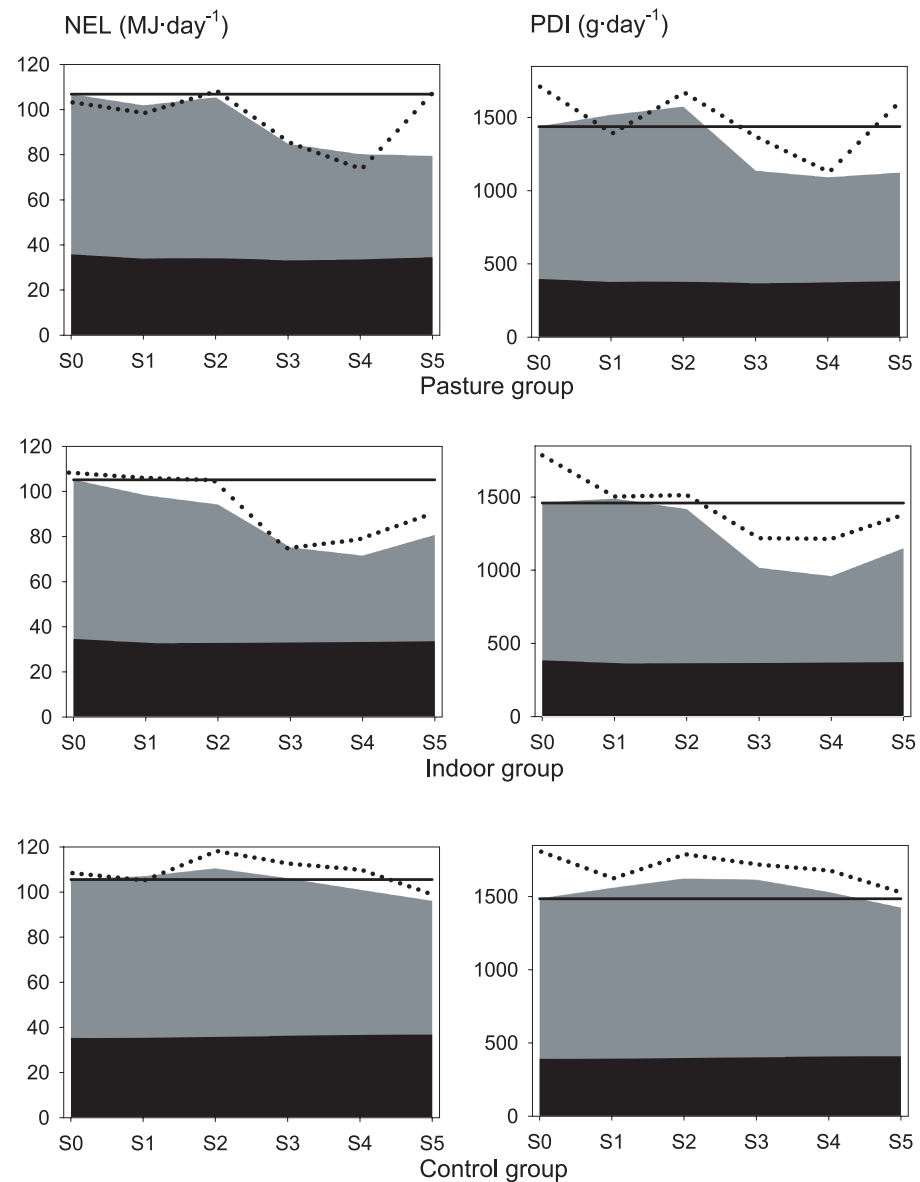

Figure 1. Intake and requirements of net energy for lactation (NEL) and of duodenal absorbable protein (PDI); calculations based on RAP [38]. Black area, actual maintenance requirements (based on regressions for lowland conditions); grey area, requirements for actual milk yield; solid line, baseline level of initial total requirements; dotted line, actual intake.

initial milk yield (Fig. 1). Cows adapted milk yield accordingly. In addition, PDI intake was becoming deficient, but was probably less limiting than NEL intake.

Apparent digestibilities of OM, NDF and ADF were significantly higher in the young lowland grass (S1) than in the control diet, but were clearly reduced both by increasing maturity of the forage and by feeding grass from the alpine site (Tab. III).

\subsection{Performance}

The body weight of the grass-fed cows decreased during S1 and, for the cows on alpine pasture, again during S3 (Tab. IV). Yield of energy-corrected milk (ECM) was relatively constant during the lowland period, except for the cows of group B during S2, which produced $15 \%$ less milk than the average of the other groups. In the alpine period, milk yield massively decreased to 


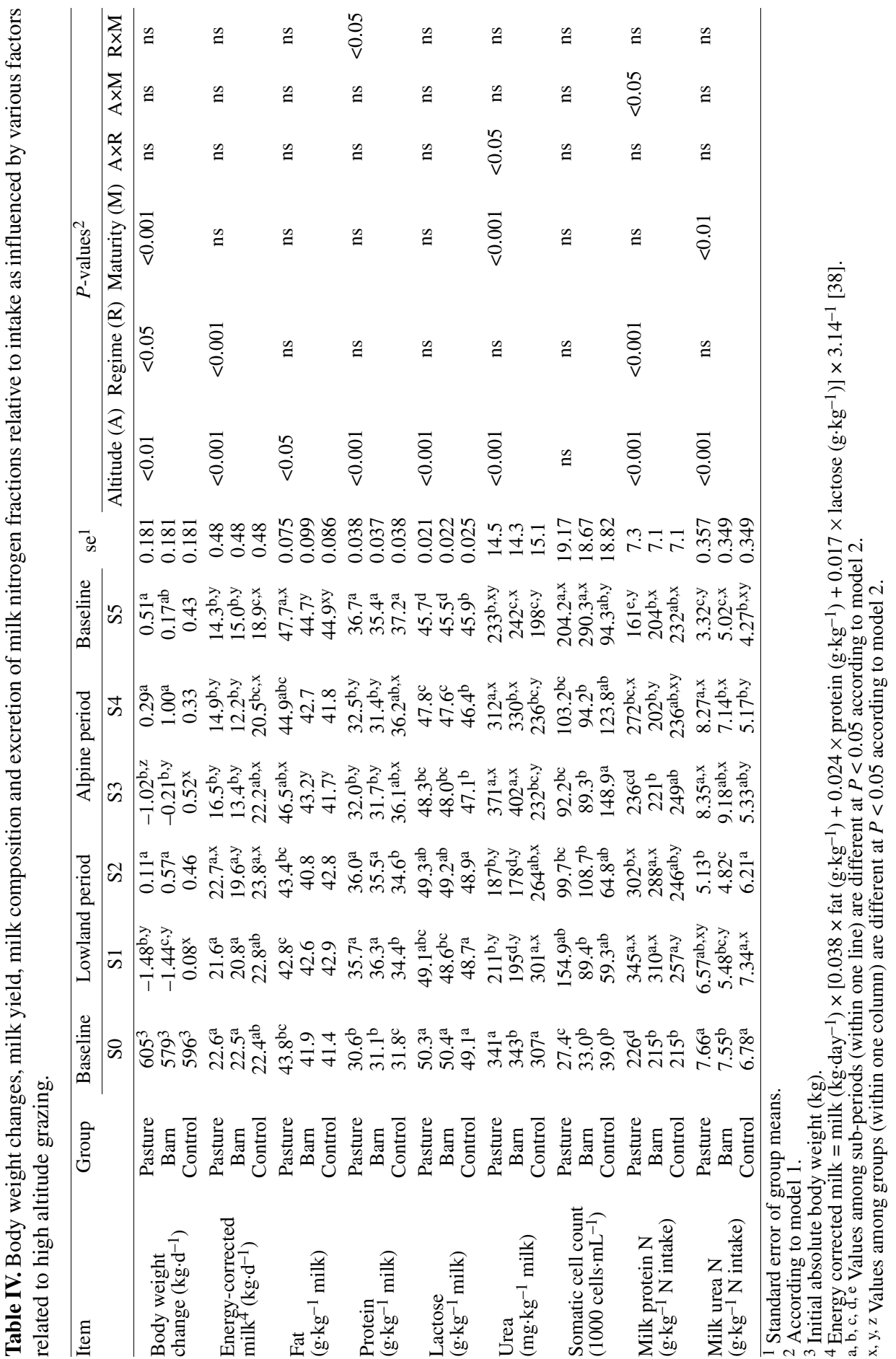


values accounting for 0.67 of the control group's yield. The barn group had a lower yield than the pasture group during all experimental periods ( $\mathrm{S} 1$ to $\mathrm{S} 4 ; P<0.001$ ). In $\mathrm{S} 5$, the milk yield of the grass-fed groups did not return to the level of the group $\mathrm{C}$, but at least no longer expressed a decline.

Milk fat content was enhanced $(P<0.05)$ on alpine pasture, but not in the barn group (significant for the total of both groups; Tab. IV). Grazing as such had no significant effect. In both grass-fed groups, milk protein content considerably decreased as soon as the cows were transferred to high altitude. Feeding the control diet again in the lowlands (S5) was associated with a recovery to almost the control group values, which constantly increased with time. Milk lactose content decreased throughout the experiment in all groups. This may have been responsible for the apparent altitude effect (Tab. IV), which therefore obviously was an artefact. The somatic cell count rose in all groups with time, but time was significant only for the $\mathrm{P}$ group. No systematic treatment effects were observed, except that cell counts increased considerably in $\mathrm{P}$ and $\mathrm{B}$ cows after the end of the alpine period. The efficiency of transfer of dietary $\mathrm{N}$ into milk protein was clearly higher with feeding lowland grass than with the control diet. This advantage disappeared during the alpine period. Simultaneously, milk urea concentration declined when the grass feeding started in the lowlands, but increased more than proportionately after transport to the alpine location. Thus, the ratio of milk urea $\mathrm{N}$ to $\mathrm{N}$ intake was higher on the alpine site. There was a clear influence of increasing grass maturity towards lower milk urea levels, particularly at the alpine site. In S5, average values were low in all groups of cows.

\subsection{Properties relevant for cheese-making}

The casein number $(\mathrm{CN})$ increased with the beginning of grass feeding and remained high in the pasture group during the entire experiment, including S5 (Tab. V). In addi- tion, $\mathrm{CN}$ was occasionally higher in the milk of group B than in group C. In all groups, there was a tendency for an increasing $\mathrm{CN}$ with progressing lactation. At both altitudes and in both grass-fed groups, but particularly on pasture, the apparent plasmin activity increased with the maturity of the grass (maturity effect, $P<0.01$ ). However, simultaneously to mature grass feeding, there was an unexplainable and concomitant increase in plasmin activity in the milk of the control cows. No systematic difference between the grass-fed groups and group $\mathrm{C}$ was found. There was no change in apparent plasmin activity when the cows were transferred to high altitude. Grass maturity furthermore affected the apparent plasminogen-derived activity, but in the opposite way, indicating an increased concentration of the plasminogen activator. Additionally, plasminogen-derived activity declined in the high altitude period, when the difference with the $\mathrm{C}$ cows was significant. Rennet coagulation time was not affected by any of the treatments, but coagulation dynamics $\left(\mathrm{K}_{20}\right)$ and curd firmness $\left(A_{2 R}\right)$ were impaired when the cows received grass at the alpine site, particularly when they were actively grazing. The unfavourable trend in $\mathrm{K}_{20}$ was even more pronounced in the last alpine measurement period with the mature alpine grass. During the lowland period, $\mathrm{P}$ cows had more favourable $\mathrm{K}_{20}$ and $A_{2 R}$ values than the $B$ and $C$ cows (significant for $A_{2 R}$ ).

\section{DISCUSSION}

\subsection{Factors explaining the effect of high altitude grazing on intake}

A serious and negative influence of an alpine period on dairy cow metabolism and performance repeatedly reported so far was the reduction of feed intake. However, previous findings suggested that this is valid only for an initial adaptation period of about 2 weeks [6, 7, 26, 33] and permanent intake depressions at high altitude are only reported 


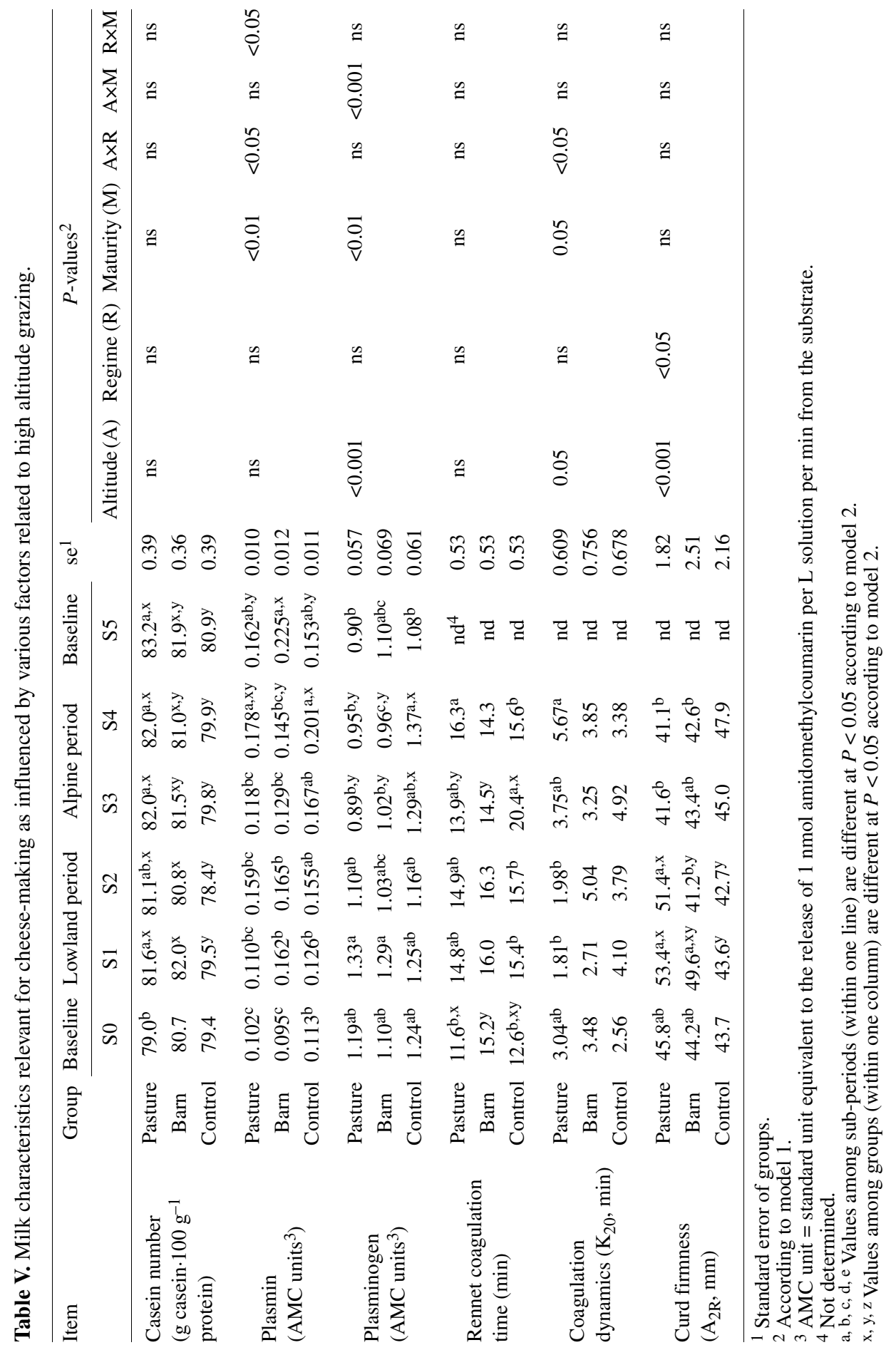


for cows kept in barn [14]. In the experiment presented here, the decrease of intake lasted for the entire alpine period of 7 weeks, both on pasture and in barn. A plausible explanation would be that the higher fibre content of the alpine grass limited intake by gut fill [36]. However, the amount of NDF ingested during S2 shows that fibre intake capacity of the cows was not stressed in S3 and S4, thus indicating that NDF was not the limiting factor for intake at high altitude.

An increased proportion of indigestible $\mathrm{OM}$ in the feed would also decrease OM intake [1]. As was expected from the results obtained on comparable alpine pastures [6, 22 ], the apparent digestibility in our study was slightly lower when feeding the alpine compared to the lowland grass. The magnitude of this reduction was not as important as described elsewhere for alpine pastures [10] and for hay of alpine and lowland origin [31]. Even the 10\% difference in apparent digestibility, as previously found between alpine and lowland hay [31], did not result in any differences in voluntary DM intake. Thus, it is assumed that the small difference in digestibility found in the present study between the lowland and alpine pasture grass was not important enough to explain the intake reduction. A further factor, which could have limited feed intake of dairy cows was intensive physical activity [17], being an issue on the often steep slopes of the alpine pastures. However, the pasture group did not differ in intake from the barn group. Thus, it seems reasonable to also assume that movement was not the major factor that reduced intake.

It is therefore hypothesised that the most important factor limiting feed intake at high altitude was hypoxia. Investigated under simulated high altitude conditions, hypoxia has been demonstrated to cause intake reductions independently of the diet or climatic influences [7, 26]. Strong reduction of intake also occurs in humans staying at high altitude, even in situations not caused by acute mountain sickness [2]. At altitudes of more than $3000 \mathrm{~m}$ a.s.l., test persons described an elevated sensitivity to taste, particularly to glucose and sodium chloride, with a consequent reduction of up to $40 \%$ of the baseline energy intake [41]. Since a selective intake behaviour was observed at high altitude in the present study, enhanced taste sensitivity could have played a role.

\subsection{Factors explaining the effect of high altitude grazing on performance and $\mathbf{N}$ utilisation}

Performance of cows has often been found to be significantly impaired at high altitude [6, 14, 31, 45]. Limited intake of digestible OM clearly resulted in a lack of energy in metabolism. This is further emphasised by the marked increase in milk urea concentration and decrease in milk protein content [23] in both alpine sub-periods. The lack of energy was associated with a lack in metabolically available protein (PDI) mainly because of the limited amount of fermentable OM. This deficiency of nutrients and energy at high altitude can be corrected for by a mobilisation of body reserves and/or a reduction of milk yield. The extent to which cows respond in either way varies considerably $[6,14,22,31,45]$. In the present study, a large proportion of the deficit was compensated for by a corresponding reduction in performance. Applying the standard estimates for lowland resting maintenance energy requirements [38], as done in Figure 1, suggests that the energy requirements were adapted to the energy intake by a reduced milk yield. The resulting net energy balance never became negative. However, blood plasma levels of $\beta$-hydroxybutyrate and nonesterified fatty acids as indicators for mobilisation were significantly increased at the alpine site (data published in [32]), suggesting that calculations and live weight data underestimated mobilisation. This indicates that cows in hypoxic conditions have maintenance requirements $[14,27]$ for which the lowland resting requirement data applied in Figure 1 did not account for. Body weight 
changes in group $\mathrm{P}$, which did not occur in group $\mathrm{B}$, were indicative of the additional energy requirements in S3 for grazing activity [17]. This was specifically related to grazing at high altitude and on steep slopes, since this effect was not found in the lowlands when comparing $\mathrm{P}$ and $\mathrm{B}$ cows (S1).

The grass at both sites had comparably low CP contents in both maturity stages. This, and the higher $\mathrm{CP}$ contents of the hay and the grass silage, explain the better $\mathrm{N}$ utilisation and the lower milk urea content of the grass-fed cows in the lowlands compared to cows fed the control diet (period S0 and control group). Despite unchanged $\mathrm{CP}$ contents and lower feed intake, $\mathrm{N}$ utilisation dropped considerably as soon as cows were transferred to high altitude, as noted in a previous study [14], and milk urea contents significantly increased like in other investigations [43]. The high milk urea contents may at least partly reflect the massively reduced milk protein output resulting from declines in both milk yield and protein content. This is explained by the deficit in energy necessary for milk protein formation [14].

\subsection{Factors explaining the effect of high altitude grazing on milk composition and properties relevant for cheese making}

A clear influence of high altitude grazing on major milk constituents was found. With the lowland grass, milk protein content was significantly increased even without concentrate supplementation. Consecutively, protein content was clearly impaired by the alpine period, as expected from several other studies [5, 14, 33, 45]. Our previous study [33] demonstrated that the reduction of milk protein content was caused by both deficient nutrient supply and hypoxia (the latter supposedly active through lower metabolic energy availability [27, 28]). This interpretation can be upheld since grazing did not contribute an additional effect.

The significant increase of milk fat content during the alpine period is in accord- ance with Zemp et al. [45] and partly with Leiber et al. [31] but in contrast to Bugaud et al. [12]. Besides the concentration effect, caused by the depression in milk yield [31], this increase might have resulted from body fat mobilisation in the first alpine period (S3; [31]) and from the increase in fibre content of the grass [13] in S4. However, there was no corresponding increase in milk fat content in the lowlands with increasing sward maturity. The continuous decrease of lactose content throughout the experiment took place in all three groups during the entire experiment and thus was more likely an effect of the progressing lactation [19] than an altitude or sward maturity effect. No clear effects of the alpine period on somatic cell counts (SCC) were observed, which was different from other studies [5, 30]. The elevated SCC of the cows returning from the alpine site might have been a consequence of transport stress.

Cheese yield and curd firmness are determined by milk protein concentration and casein number [CN; 25, 35]. As discussed above and shown previously [33], the reduction of the milk protein yield was simultaneously caused by low energy supply and hypoxia. As a result, the grass-fed groups at high altitude produced on average $40 \%$ less casein per day in both alpine subperiods compared to the lowland control group. An obvious effect of grass-only feeding, however, was the increase in $\mathrm{CN}$, which was maintained in both groups throughout the entire experiment, independently from alterations in milk yield and milk protein content. This effect of a grass diet was also found by Christian et al. [15], and the results of Coulon et al. [18] indicate that increasing dietary fibre contents might be associated with a higher $\mathrm{CN}$. However, with respect to the impaired rennet coagulation properties, this was not sufficient to overrule the depression of milk protein content during the alpine period. This explains at least partially the less favourable rennet coagulation properties [5, 33]. Additionally, concentrate feeding has been shown to be relatively inefficient in improving rennet coagulation 
properties on alpine pastures [5,9] presumably because the substitution of grass by concentrate in intake can account for more than one $\mathrm{kg}$ DM per $\mathrm{kg}$ of concentrate DM when cows of relatively high performance are otherwise forced to graze until complete darkness [6]. Under these conditions, supplementation results in only moderate effects on ruminal nutrient supply.

Elevated plasmin activity in the milk is assumed to impair the process of cheese formation since it breaks down $\beta$-casein, and the products are lost with the whey [34, 42]. However, it probably requires very pronounced changes in plasmin activity to be noticeable in rennet coagulation properties [16]. On the contrary, plasmin activity is known to facilitate cheese ripening and flavour development [11]. It has been described that plasmin and plasminogen-derived activities are increased in the milk of cows grazing alpine pastures [12]. Like in the previous study [33], we did not find such an enhancement of the plasmin system during the alpine period. Plasminogen-derived activity in the milk was even significantly decreased in the actual and in the previous study in cows on high altitude. This was probably not caused by a higher activation of plasminogen to plasmin, since plasmin activity was not concomitantly increased. This reduction in plasminogen-derived activity in alpine milk is surprising, because the plasmin system is expected to be up-regulated at high altitude [21] due to its relation to the fibrin system [3].

Clear effects on the plasmin system were found in relation to forage maturity. Plasmin activity increased and plasminogenderived activity decreased with increasing maturity of the sward, but these changes were too weak to clearly affect rennet coagulation properties. Buchin et al. [11] described an influence of pasture type on plasmin and plasminogen-derived activity in cheese. However, it was not determined whether this was related to plant species or to season and plant development [37]. Our results suggest the latter.
Grazing activity might also enhance plasmin activity: physical motion may increase SCC in the milk [17] and the latter is related to an increased plasmin activity [44]. However, the pasture and the barn group did not differ in the plasmin-related traits and in SCC, suggesting that, in this study, physical activity alone did not influence the plasmin system in milk. The results also indicate that plasmin activity and SCC might be independent from each other.

\section{CONCLUSION}

The experiment confirmed previous findings of adverse impacts of an alpine period on yield, protein content and cheese-making properties of milk. Diet and hypoxiarelated factors, in particular anorexia, were identified as the main factors, while feeding regime (grazing vs. barn feeding) and maturity of the sward seemed to be of lesser importance. This is astonishing since major differences in the quality of young and mature grass were obvious, and these differences were similar in magnitude to those occurring between lowland and alpine grass. Obviously, the adaptation capacity of the cows is more limited when changes in feed quality are abrupt and associated with other environmental changes such as transport to high altitude. The lack of relevant differences in many traits between grazing cows and cows fed grass in barn supports the validity of the data obtained in a previous study carried out only in the barn [31,33], where the relative importance of altitude and diet origin and type was quantified. These previous results, in conjunction with the present data, show that efficient feeding intervention options for alpine summer grazing have to be developed from the beginning of the alpine period, i.e., even at a time when the grass is still of relatively high quality. A promising way for the compensation of economic losses resulting from alpine grazing could be the skilful marketing of alpine products by promoting the human-health relevant advantages of alpine milk and milk products [29, 32]. 


\section{ACKNOWLEDGEMENT}

We gratefully acknowledge the assistance of Daniel Nigg, the agricultural support by the staff of the ETH research stations, the laboratory work of Muna Mergani and Seher Ayra, and the assistance of Debora Santschi in preparing the manuscript. This work was supported by a grant of the Swiss Federal Office of Agriculture (BLW), Berne.

\section{REFERENCES}

[1] Allen M.S., Physical constraints on voluntary intake of forages by ruminants, J. Anim. Sci. 74 (1996) 3063-3075.

[2] Baker C.J., Rock P.B., Fulco C.S., Trad L.A., Cymerman A., High altitude-induced anorexia, FASEB J. 3 (1987) 4424.

[3] Bastian E.D., Brown R.J., Plasmin in milk and dairy products: an update, Int. Dairy J. 6 (1996) 435-457.

[4] Berry N.R., Scheeder M.R.L., Sutter F., Kröber T.F., Kreuzer M., The accuracy of intake estimation based on the use of alkane controlledrelease capsules and faeces grab sampling in cows, Ann. Zootech. 49 (2000) 3-13.

[5] Berry N.R., Büeler T., Jewell P.L., Sutter F., Kreuzer M., The effect of supplementary feeding on composition and renneting properties of milk from cows rotationally grazed at high altitude, Milchwissenschaft 56 (2001) 123-126.

[6] Berry N.R., Sutter F., Bruckmaier R.M., Blum J.W., Kreuzer M., Limitations of high alpine grazing conditions for early lactating cows: effects of energy and protein supplementation, Anim. Sci. 73 (2001) 149-162.

[7] Bianca W., Puhan Z., Untersuchungen über den Einfluss der Luftverdünnung auf einige physiologische Grössen von Kühen sowie auf die Menge und Beschaffenheit der Milch, Schweizer. Landwirtschaftl. Forsch. 13 (1974) 463-489.

[8] Bordin G.F., Cordeiro-Raposo F., De La Calle B., Rodriguez A.R., Identification of major bovine milk proteins by liquid chromatography, J. Chromat. A 928 (2001) 63-76.

[9] Bovolenta S., Ventura W., Piasentier E., Malossini F., Supplementation of dairy cows grazing an alpine pasture: Effect of concentrate level on milk production, body condition and rennet coagulation properties, Ann. Zootech. 47 (1998) 169-178.
[10] Brühlmann M., Thomet P., Verlauf des quantitativen und qualitativen Futterangebotes auf Alpweiden, Landwirtsch. Schweiz 4 (1991) 547-554.

[11] Buchin S., Martin B., Dupont D., Bornard A., Achilleos C., Influence of the composition of alpine highland pasture on the chemical and sensory properties of cheese, J. Dairy Res. 66 (1999) 579-588.

[12] Bugaud C., Buchin S., Coulon J.-B., Hauwuy A., Dupont D., Influence of the nature of alpine pastures on plasmin activity, fatty acid and volatile compound composition of milk, Lait 81 (2001) 401-414.

[13] Chilliard Y., Ferlay A., Doreau M., Effect of different types of forages, animal fat or marine oils in cow's diet on milk fat secretion and composition, especially conjugated linoleic acid (CLA) and polyunsaturated fatty acids, Livest. Prod. Sci. 70 (2001) 31-48.

[14] Christen R.E., Kunz P.L., Langhans W., Leuenberger H., Sutter F., Kreuzer M., Productivity, requirements and efficiency of feed and nitrogen utilization of grass-fed early lactating cows exposed to high Alpine conditions, J. Anim. Physiol. Anim. Nutr. 76 (1996) 22-35.

[15] Christian M.P., Grainger C., Sutherland B.J., Mayes J.J., Hannah M.C., Kefford B., Managing diet quality for cheddar cheese manufacturing milk. 2. Pasture v. grain supplements, J. Dairy Res. 66 (1999) 357-363.

[16] Considine T., McSweeney P.L.H., Kelly A.L., The effect of lysosomal proteinases and plasmin on the rennet coagulation properties of skim milk, Milchwissenschaft 57 (2002) 425428.

[17] Coulon J.-B., Pradel P., Effect of walking on roughage intake and milk yield and composition of Montbéliarde and Tarentaise dairy cows, Ann. Zootech. 46 (1997) 139-146.

[18] Coulon J.-B., Hurtaud C., Rémond B., Vérité R., Factors contributing to variation in the proportion of casein in cow's milk true protein: a review of recent INRA experiments, J. Dairy Res. 65 (1998) 375-387.

[19] Dillon P., Buckley F., O'Connor P., Hegarty D., Rath M., A comparison of different dairy cow breeds on a seasonal grass-based system of milk production: 1. Milk production, live weight, body condition score and DM intake, Livest. Prod. Sci. 83 (2003) 21-33.

[20] Dove H., Mayes R.W., Plant wax components: a new approach to estimating intake and diet composition in herbivores, J. Nutr. 126 (1996) 13-26. 
[21] Ernst E. Altmann C. Saradeth T., Hemorheological changes following exposure to moderately high altitude, Clin. Hemorheol. 11 (1991) 303-307.

[22] Estermann B.L., Wettstein H.-R., Sutter F., Kreuzer M., Nutrient and energy conversion of grass-fed dairy and suckler beef cattle kept indoors and on high altitude pasture, Anim. Res. 50 (2001) 477-493.

[23] Frand X., Froidmont E., Bartiaux-Thill N., Decruyenaere V., Van Reusel A., Fabry J., Utilization of milk urea concentration as a tool to evaluate dairy herd management, Anim. Res. 52 (2003) 543-551.

[24] Gruber L., Steinwidder A., Stefanon B., Steiner B., Steinwender R., Influence of grassland management in alpine regions and concentrate level on $\mathrm{N}$ excretion and milk yield of dairy cows, Livest. Prod. Sci. 61 (1999) 155170.

[25] Guinee T.P., Mulholland E.O., O'Brien B., Murphy J.J., Effect of diet on the suitability of mid-lactation bovine milk for cheddar cheese manufacture, Aust. J. Dairy Technol. 56 (2001) 3-8.

[26] Hays F.L., Bianca W., Pulmonary hypertension, blood coagulation and Aspirin treatment in high altitude exposed cattle, Int. J. Biometeor. 20 (1976) 56-60.

[27] Hays F.L., Bianca W., Näf F., Effects of exercise on young and adult cattle at low and high altitude, Int. J. Biometeor. 22 (1978) 147-158.

[28] Kirchgessner M., Kreuzer M., Roth-Maier D.A., Milk urea and protein content to diagnose energy and protein malnutrition of dairy cows, Arch. Anim. Nutr. 36 (1986) 192-197.

[29] Kraft J., Collomb M., Möckel P., Sieber R., Jahreis G., Differences in CLA isomer distribution of cow's milk lipids, Lipids 38 (2003) 657-664.

[30] Lamarche A., Martin B., Hauwuy A., Coulon J.-B., Poutrel B., Evolution of milk somatic cell count of cows grazing an alpine pasture according to the infection of udder by pathogens, Ann. Zootech. 49 (2000) 45-54.

[31] Leiber F., Kreuzer M., Jörg B., Leuenberger H., Wettstein H.-R., Contribution of altitude and alpine origin of forage to the influence of alpine sojourn of cows on intake, nitrogen conversion, metabolic stress and milk synthesis, Anim. Sci. 78 (2004) 451-466.

[32] Leiber F., Kreuzer M., Nigg D., Wettstein H.R., Scheeder M.R.L., A study on the causes for the elevated $n-3$ fatty acids in cows' milk of alpine origin, Lipids 40 (2005) 191-202.

[33] Leiber F., Nigg D., Kunz C., Scheeder M.R.L., Wettstein H.-R., Kreuzer M., Protein compo- sition, plasmin activity and cheese-making properties of cow's milk produced at two altitudes from hay of lowland and high alpine origin, J. Dairy Res. 72 (2005) 65-74.

[34] Mara O., Roupie C., Duffy A., Kelly A.L., The curd-forming properties of milk as affected by the action of plasmin, Int. Dairy J. 8 (1998) 807-812.

[35] Melilli C., Lynch J.M., Carpino S., Barbano D.M., Licitra G., Cappa A., An empirical method for prediction of cheese yield, J. Dairy Sci. 85 (2002) 2699-2704.

[36] Mertens D.R., Regulation of forage intake, in: Fahey G.C., Collins M., Mertens D.R., Lowell D., Moser E. (Eds.), Forage quality, evaluation, and utilization, University of Nebraska, 1994, pp. 450-492.

[37] Nicholas G.D., Auldist M.J., Molan P.C. Stelwagen K., Prosser C.G., Effects of stage of lactation and time of year on plasminderived proteolytic activity in bovine milk in New Zealand, J. Dairy Res. 69 (2002) 533540.

[38] RAP (Station fédérale de recherches en production animale), Fütterungsempfehlungen und Nährwerttabellen für Wiederkäuer, 4th ed., Zollikofen, Switzerland, Landwirtschaftliche Lehrmittelzentrale, 1999.

[39] Richardson B.C., Pearce K.N., The determination of Plasmin in dairy products, N.Z. J. Dairy Sci. Technol. 16 (1981) 209-220.

[40] Rook A.J., Tallowin J.R.B., Grazing and pasture management for biodiversity benefit, Anim. Res. 52 (2003) 181-189.

[41] Singh S.B., Sharma A., Yadav D.K., Verma S.S., Srivastava D.N., Sharma K.N., Selvamurthy W., High altitude effects on human taste intensity and hedonics, Aviat. Space Environ. Med. 68 (1997) 1123-1128.

[42] Srinivasan M., Lucey J.A., Effects of added Plasmin on the formation and rheological properties of rennet-induced skim milk gels, J. Dairy Sci. 85 (2002) 1070-1078.

[43] Ubertalle A., Profiti M., Battaglini L.M., Mimosi A., Fortina R., Milk urea nitrogen of Italian Friesian and Valdostana R. P. dairy cattle, Sci. Tecn. Latt. Cas. 49 (1998) 249-265.

[44] Urech E., Puhan Z., Schällibaum M., Changes in milk protein fraction as affected by subclinical mastitis, J. Dairy Sci. 82 (1999) 24022411

[45] Zemp M., Leuenberger H., Künzi N., Blum J.W., Influence of high altitude grazing on productive and physiological traits of dairy cows. I. Influence on milk production and body weight, J. Anim. Breed. Genet. 106 (1989) 278-288. 